Montreal, Canada

Cite this as: BMJ 2020;370:m2855 http://dx.doi.org/10.1136/bmj.m2855 Published: 15 July 2020

\section{Covid-19: Trump sidelines “lying” CDC from collecting mortality data}

\section{Owen Dyer}

Data on hospital admissions and deaths from covid-19 in the US are no longer being sent to the Centers for Disease Control and Prevention (CDC), after the Trump administration told hospital officials to send it instead to a federally contracted health data company, starting on 15 July.

The move to strip the nation's premier health agency of its principal function during a pandemic is unprecedented and raises questions about the government's purpose in corralling the data.

The new rule dates from 10 July but was posted inconspicuously on the Department of Health and Human Services website, and only attracted media notice on 14 July.

It says, "As of 15 July 2020, hospitals should no longer report the covid-19 information in this document to the National Healthcare Safety Network (NHSN) site."

Instead of the NHSN-the country's source of infectious disease data for decades-hospitals may send the information through their state, if they already were, or directly to TeleTracking, a Pittsburgh based health data company that has been awarded a non-competitive federal contract for the job. Final figures will be sent to the CDC, which will pass them on to the public without any role in compiling them.

Deaths from coronavirus will be a key metric on which the government is judged in the coming election. Trump has expressed openness to massaging covid-19 data, musing aloud on several occasions that slowing testing would improve his image by uncovering fewer cases.

States run by Trump allies have worked to lower covid-19 death counts. In Alabama, state panels attribute some deaths in covid-19-positive patients to comorbid conditions, ${ }^{2}$ and in Florida, state medical examiners have been barred from directly reporting deaths in the usual manner. ${ }^{3}$

In a letter last week to hospital industry leaders, health secretary Alex Azar and White House coronavirus response coordinator Deborah Birx wrote that the National Guard would enter and take over the task of data entry in hospitals that the administration claimed were underperforming at reporting. After strong pushback from the American Hospital Association, references to the National Guard were removed from a later draft sent on July 14.4

“It makes no sense,” Rick Pollack, president of the American Hospital Association, told the Washington Post. "Certainly, the expertise of the National Guard can be used in a more productive way."

Trump's sharpest attack yet on the CDC came this week when he retweeted a message from a supporter, former game show host Chuck Woolery, who wrote, "Everyone is lying. The CDC, media, Democrats, our doctors, not all but most, that we are told to trust. I think it's all about the election."

Trump criticised the CDC’s school reopening guidelines in a tweet last week. "I disagree with @CDCgov on their very tough \& expensive guidelines for opening schools," he wrote. "I will be meeting with them!!!"

The CDC initially responded with a statement that it would not be changing the guidelines, but later said they would be "updated" this week.

The apparent concession to Trump drove four former CDC directors to write a Washington Post opinion piece decrying political interference. "It is extraordinary for guidelines to be undermined after their release," they wrote. "The four of us led the CDC over a period of more than 15 years, we cannot recall over our collective tenure a single time when political pressure led to a change in the interpretation of scientific evidence." 5

Also under fire from the Trump administration this week was Anthony Fauci, the government's top infectious disease expert, who has become a household name and, increasingly, a critic of the hasty state reopenings that have triggered huge spikes in infections.

Fauci, who recently revealed that he has not spoken to Trump in two months, testified to Congress that the US was losing its battle to contain the virus, and could soon be seeing 100 ooo new cases a day.

Over the weekend, Trump aides gave several media outlets a compilation of what they called Fauci's errors in the pandemic, most of them occasions when he understated its severity early on. Asked later to comment on the list, President Trump said, "Dr Fauci is a nice man, but he's made a lot of mistakes.”

Dan Scavino, White House deputy chief of staff for communications, shared and later deleted a cartoon on his Facebook page that depicted Fauci flushing the US economy down the drain. White House trade advisor Peter Navarro attacked Fauci in a 14 July editorial in USA Today, calling him "wrong about everything." 6

The next day, amid a widespread backlash, the White House distanced itself from the article. "The Peter Navarro op-ed didn't go through normal White House clearance processes and is the opinion of Peter alone," 
White House director of strategic communications Alyssa Farah tweeted. “@realDonaldTrump values the expertise of the medical professionals advising his administration.”

The attacks on Fauci, wrote Howard Bauchner, editor of the Journal of the American Medical Association, "are not only unseemly and unfair, but reveal a lack of commitment to the health and wellbeing of all Americans."7

1 US Department of Health and Human Services. covid-19 guidance for hospital reporting and faqs for hospitals, hospital laboratory, and acute care facility data reporting. 10 July 2020. www.hhs.gov/sites/default/files/covid-19-faqs-hospitals-hospital-laboratory-acute-care-facility-data-reporting.pdf.

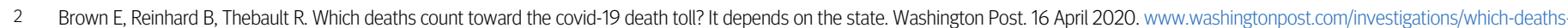
count-toward-the-covid-19-death-toll-it-depends-on-the-state/2020/04/16/bca84ae0-7991-11ea-a130-df573469f094_story.html.

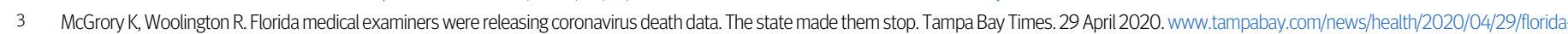
medical-examiners-were-releasing-coronavirus-death-data-the-state-made-them-stop.

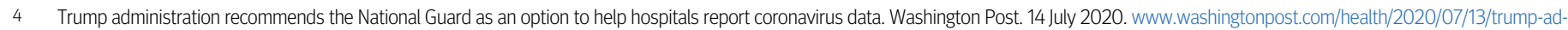
ministration-recommend-national-guard-an-option-help-hospitals-report-covid-19-data.

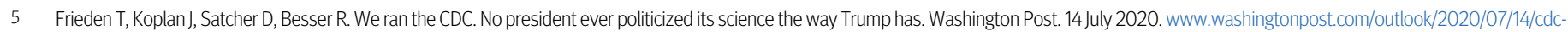
directors-trump-politics.

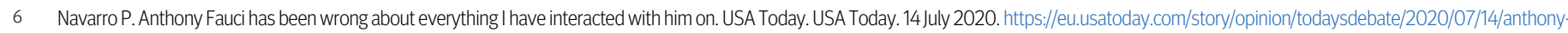
fauci-wrong-with-me-peter-navarro-editorials-debates/5439374002.

7 Bauchner H. July 2020. https://twitter.com/JAMA_current/status/1283095399574667267. 